\title{
Ihor Usatenko
}

Winnicka Akademia Kształcenia Ustawicznego igorusatenko88@gmail.com

\section{Fenomen gościnności środkowoeuropejskiej w ujęciu historycznym}

\begin{abstract}
Abstrakt: Artykuł dotyczy zjawiska gościnności rozpatrywanego w perspektywie historycznej. Rozważania pokazują, że tradycja gościnności w Europie Środkowej jest głęboko historycznie zakorzeniona i mocno związana z rozmaitymi procesami społeczno-politycznymi i gospodarczymi, które zachodziły w różnych epokach.
\end{abstract}

Słowa kluczowe: gościnność, staropolska gościnność, Europa Środkowa

Pomimo tego, że próby teoretycznego ujęcia rozwojowej oraz społeczno-politycznej odrębności Europy Środkowo-Wschodniej przez długi czas były w centrum uwagi badaczy, zarówno polskich, jak i zagranicznych, zgłębienie pewnych aspektów tej problematyki wciąż pozostaje zadaniem aktualnym. Jednym z takich zagadnień jest wskazanie charakterystycznych cech życia codziennego, a także badanie obyczajowości w kulturze mieszkańców tego regionu. Przykładem szeroko rozpowszechnionej tradycji jest zjawisko społeczne gościnności. Pod hasłem tym rozumiano najczęściej uprzejmość okazywaną przybywającej w odwiedziny obcej osobie (gościowi), zapewnienie jej ochrony i opieki. W Europie obszar obejmujący Polskę, Węgry, Czechy i Słowację jest tradycyjnie postrzegany jako taki, w którym instytucja gościnności stanowi dla mieszkańców jeden z priorytetów. Nie do końca zrozumiała pozostaje jednak geneza tej tradycji, a także czynniki, które wpłynęły na jej powstanie i ewolucję w przekroju historycznym.

W związku z tym celem artykułu jest analiza wpływu procesów społecznopolitycznych i gospodarczych na zjawisko gościnności w krajach Europy Środkowej. Aby zrozumieć, w jakich okolicznościach powstała ta tradycja (kojarzona przez długi czas z obywatelami całego regionu), przydatne jest zbadanie jej podstaw oraz spojrzenie na nią jako na funkcję, która miała konkretne cele. 
Według opinii szkockiego antropologa społecznego i historyka religii Jamesa Georga Frazera, wyrażonej w jego klasycznej pracy Złota gałaź. Studia z magii i religii, moralne więzy gościnności, honoru i uczciwości w społeczeństwach zbieracko-myśliwskich zostały wzmocnione przez nieuzasadniony niczym strach i fałszywe wyobrażenie o przyczynowości ${ }^{1}$. Przykładowo, o ile początkowo rytuał jedzenia wspólnie z gościem wynikał z chęci uniknięcia przez gospodarza szkodliwych skutków działań magicznych lub prób otrucia ${ }^{2}$, o tyle z czasem zwyczaj ten zaczął nabierać innego charakteru — od wspólnego działania w atmosferze świętości (w społeczeństwach prehistorycznych i starożytnych) przeszedł w zwykłą normę etykiety (w czasach średniowiecza). Zdaniem Norberta Eliasa, uznawanego za największy autorytet w dziedzinie analizy przemian obyczajowości, średniowieczny standard nie może być uważany za statyczny, a bliższe jego poznanie pozwala w nim dostrzec cechy tradycji narodowych ${ }^{3}$. Spostrzeżenie to potwierdza zjawisko gościnności, która - jako jedna z najstarszych instytucji społecznych - ewoluowała od filozofii wzajemności do usługi świadczonej za nagrodę. Dotyczy to w równym stopniu chrześcijańskiej gościnności instytucji kościelnych i bezosobowej płatnej gościnności zajazdów.

Jedną z najważniejszych funkcji gościnności w średniowieczu i w czasach nowożytnych było zobowiązanie podwładnych do utrzymywania na własny koszt ważniejszego od siebie dygnitarza. Praktyka - znana jako servitium regis ${ }^{4}$ (na terenie Niemiec) lub gistum regis (we Francji) - świadczyła o tym, że nowe centra władzy, zwłaszcza zamki senioralne, potrafiły wciągnąć otaczającą ludność w sferę wpływu swej dominacji i wyzysku. Kwaterunek senioralny rozprzestrzeniał się w Europie Zachodniej w okresie rozwiniętego feudalizmu (a w Europie Centralnej w czasach gospodarki czynszowej — od połowy XII wieku do połowy XV wieku) jako sposób utrzymywania rozrastającej się armii i jeden z głównych obowiązków narzuconych przez przywództwo polityczne. Innymi słowy, przywilej seniorów, który polegał na prywatyzacji niegdyś publicznych prerogatyw, był oparty na prawie silniejszego ${ }^{5}$.

W kontekście organizacji wewnętrznej tworzącego się państwa Piastów pisał o tym Jerzy Topolski: „Książę gnieźnieński ściągał do swych magazynów daniny

\footnotetext{
${ }^{1}$ J.G. Frazer, Złota gałąź. Studia z magii i religii, przeł. H. Krzeczkowski, Warszawa 2017, s. 155.

2 Ibidem, s. 157.

${ }^{3}$ N. Elìas, Proces civilizaciï. Sociogenetični i psihogenetičnì doslidžennâ, perekl. O. Logvinenko, Kiïv 2003, s. 102.

${ }^{4} \mathrm{O}$ servitium regis w znaczeniu opłaty pieniężnej przeznaczonej na utrzymanie dworu królewskiego w podróży zob. K. Modzelewski, Organizacja gospodarcza państwa piastowskiego X-XIII wiek, Poznań 2000, s. 25; C. Brühl, Fodrum, Gistum, Servitium Regis. Studien zu den wirtschaftlichen Grundlagen des Königtums im Frankenreich und in den fränkischen Nachfolgestaaten Deutschland, Frankreich und Italieni, Köln 1968.

${ }^{5}$ I.V. Dubrovskij, Gostepriimstvo, w: Slovar' srednevekovoj kul'tury, red. A.Â. Gurevič, Moskva 2003, s. $120-125$.
} 
dla utrzymania dworu i drużyny (zwierzęta hodowlane, zboże, miód, skórki zwierzęce, żelazo i ewentualnie inne produkty). Ponadto $\mathrm{z}$ racji swych stałych objazdów w kraju książę obciążył ludność obowiązkiem goszczenia go i jego ludzi. Była to tzw. gościna”.

Organizacja pobytu i przygotowanie kwatery seniora (suzerena) wymagały także wytworzenia specyficznego ceremoniału i skodyfikowania norm postępowania. Skutkiem tego procesu, o którym pisał Jan Stanisław Bystroń w drugim tomie Dziejów obyczajów w dawnej Polsce, była dość skomplikowana etykieta gościn (łącznie ze specjalnymi, czasem kuriozalnymi manierami witania, żegnania i w ogóle oddawania czci) ${ }^{7}$. Obowiązki kwaterunkowe w Europie Zachodniej zaczęły zanikać w okresie od XIV do XVIII wieku z powodu komercjalizacji instytucji hotelarstwa i zmiany w relacjach władzy, natomiast w niezmodernizowanej Europie Środkowej możnowładcy kontynuowali średniowieczne zwyczaje i - wbrew spadkowi dochodów - jeszcze przez długi czas nie zdołali porzucić dawnego kodeksu postępowania. W każdej grupie społecznej powstał nieco inny zbiór norm i zasad, obowiązujący tylko w tym określonym środowisku; do najbardziej znamienitych można zaliczyć tradycje szlachty. $Z$ tego też powodu pojęcie staropolskiej gościnności stało się wyrażeniem znanym powszechnie nie tylko w polskim kontekście kulturowym, lecz także w skali całego regionu. Ze staropolską gościnnością wiązała się często irracjonalna zbytkowność uczt, na które składały się nazbyt kosztownie zastawione stoły, nadmierna dekoracyjność, kłopotliwy ceremoniał i szlacheckie wybryki (znamiennego przykładu szczodrości, wierności obyczajom sarmackim oraz skłonności do popędliwości i żartów dostarcza postać Karola Stanisława Radziwiłła „Panie Kochanku”, interesująco opisana przez polskiego powieściopisarza Ignacego Chodźkę w serii opowieści Obrazy litewskie ${ }^{8}$ i białoruskiego historyka Adama Maldzisa ${ }^{9}$ ). Organizowanie wystawnych przyjęć i festynów, a także bogate ozdabianie rezydencji (również w celu wywarcia dobrego wrażenia na drugich) prowadziły często magnaterię i bogatszą szlachtę do upadłości i niewypłacalności. Tę rujnującą finansowo i moralnie skłonność przedstawicieli stanów wyższych do rozrzutności krytycznie komentowali w dobie baroku zarówno autorzy ówcześnie żyjący (Władysław Jeżowski, Jędrzej Kitowicz, Daniel Bratkowski, Wespazjan Kochowski), jak i reprezentanci polskiego oświecenia (Ignacy Krasicki) ${ }^{10}$. Utrzymanie podobnej normy postępowania na Zachodzie było źle widziane przede wszystkim

\footnotetext{
${ }^{6}$ J. Topolski, Historia Polski, Poznań 2015, s. 42.

7 J.S. Bystroń, Dzieje obyczajów w dawnej Polsce, t. 2: Wiek XVI-XVIII, Warszawa 1976, s. $149-154$.

${ }^{8}$ I. Chodźko, Obrazy litewskie, Kraków 2010, s. 227-370.

9 A. Mal'dzìs, Belarus' u lùstèrku memuarnaj Litaratury xviii stagoddzâ: narysy bytu ì zvičaâ, Mìnsk 1982.

${ }^{10}$ E. Orman, Krytyka sarmackiego ucztowania oparta na fragmentach tekstów literackich i piśmienniczych dawnych, „Ogrody Nauk i Sztuk” 2011, nr 1, s. 311-320.
} 
ze względu na pojawienie się stosunków kapitalistycznych, które wymagały stałej akumulacji kapitału, a także wzmocnienia etyki pracy spowodowanej ideologicznie procesami reformacyjnymi. Zdaniem Maxa Webera reformacja nie oznaczała całkowitego wyeliminowania dominacji Kościoła z życia codziennego, lecz była jedynie zastąpieniem poprzedniej formy dominacji inną. Zgodnie $\mathrm{z}$ takim stanowiskiem, zamiast dominacji nieobciążonej, w tych czasach często słabo namacalnej, raczej nieformalnej, przyszła bardzo uciążliwa i sztywna regulacja wszystkich zachowań, przenikająca do każdej sfery życia prywatnego i publicznego ${ }^{11}$.

Podczas gdy na Zachodzie procesy kapitalistyczne (np. rewolucja przemysłowa) dość szybko modyfikowały przepisy i zasady zachowania różnych grup społecznych, na obrzeżach kontynentu, zwłaszcza w Europie Wschodniej, sytuacja wyglądała nieco inaczej. Na przykład wybitny badacz starożytności słowiańskiej oraz zwyczajów i obyczajów ludu polskiego — Łukasz Gołębiowski — w Domach i dworach wymownie świadczył o starodawnej gościnności uczt polskich, która w tych czasach (dzieło zostało opublikowane w Warszawie w 1830 roku) była przez niego scharakteryzowana jako „wszędzie już znikająca”"12 (spostrzeżenie to przywodzi na myśl ostatnią ucztę staropolską z epopei Pan Tadeusz, powstałej — jak określił to Adam Mickiewicz — „na paryskim bruku” ${ }^{13}$ w latach 1832-1834). Autor ten, jeden z pierwszych polskich etnografów, pisał, że obyczaj polegał na tym, że

nie do karczem, do zajezdnych domów, lecz prosto w podróży udawano się do dworu, znajomego czy nieznajomego ziemianina lub proboszcza, z którym wnet tworzyła się poufałość i każdy nie za natręctwo podróżnego to uważał, lecz jakby za wyświadczoną sobie przyjacielską łaskę i przyjmował najmilej. Stąd powszechny dawniej na dworach polskich zwyczaj zostawiania kilku miejsc próżnych u stołu dla panów „zagórskich”, czyli mogących nadjechać. Stąd u możnych zawsze otwarte domy i stoły, zapraszanie raz, a na zawsze do nich i owa ludzkość w przyjęciu, że kto wszedł tylko w progi domowe z szablą u pasa, tj. człek stanu rycerskiego, i oddał cześć gospodarzowi, miał prawo z nim zasiąść do stołu. Stąd liczne uczty z okazji świąt uroczystych, imienin, zaręczyn, wesel, chrzcin, pogrzebów, nowosiedlin i przenosin, zapustów, okrężnego, łowów, objęcia urzędu ziemskiego. O którejkolwiek porze przybyłeś do domu szlacheckiego, zawsze bywałeś uraczony, czekała na ciebie zostawiona część obiadu lub oporządzona już kura, a w rychłym zastawieniu pokarmu dla gościa malował się

\footnotetext{
11 M. Veber, Protestantskaâ ètika i duh kapitalizma, per. Û.N. Davydova, Moskva 1990.

12 Ł. Gołębiowski, Domy i dwory. Przy tém opisanie aptéczki, kuchni, stołów, uczt, biesiad, trunków i pijatyki; łaźni i kąpieli; łóżek, pościeli, ogrodów, powozów i koni; błaznów, karłów, wszelkich zwyczajów dworskich i różnych obyczajowych szczegółów, Warszawa 1830, s. 78.

13 A. Mickiewicz, Pan Tadeusz czyli Ostatni zajazd na Litwie, https://lektury.gov.pl/czytaj/pantadeusz-czyli-ostatni-zajazd-na-litwie (dostęp: 17.05.2020).
} 
porządek domu, pośpiech sług, dobroć gospodarza i gospodyni. Zaprosiłeś kogo do siebie? Ten miał prawo kilku jeszcze znajomych lub przyjaciół do domu twojego przyprowadzić, albo tym sposobem zamiast kilkunastu przybywało kilkadziesiąt osób, lecz nie tworzyło to nieładu, ani zagniewania gospodarstwa. Przeciwnie, wzmagała się ich wesołość i uradowanie z przybytku gości i możności okazania dostatku i porządku domowego, a gdy czegoś zabrakło, np. pościeli, spano pokotem na sianie i nikomu do głowy nie przyszło, aby zwracać uwagę na brak wygody tam, gdzie był nadmiar serdeczności ${ }^{14}$.

Jak już wspomniano, ta nadmierna hojność oraz powszechna gotowość do przyjmowania gości każdego dnia i o każdej porze, już od połowy XIX wieku były krytykowane. Przyczyny tego tkwiły w przemianach gospodarczych (np. rewolucja przemysłowa), społecznych (uwłaszczenie chłopów w zaborach pruskim, austriackim i Królestwie Polskim) i politycznych (np. represje po powstaniach). Przeobrażenia te doprowadziły do ograniczenia zasobów materialnych szlachty i jej rozwarstwienia: część jej zasiliła szeregi inteligencji, część stała się szlachtą zaściankową.

Badaczka codzienności ziemiańskiej Maja Łozińska zwróciła uwagę, że zmiana sposobu prowadzenia majątków związana z uwłaszczeniem wymagała od właścicieli większej dyscypliny i precyzyjnego planowania coraz liczniejszych gospodarskich obowiązków. Dziedzic, osobiście doglądający prac w polu i na folwarku, nie mógł sobie pozwolić na tak intensywne życie towarzyskie jak niegdyś ${ }^{15}$.

Dobrą ilustracją korelacji między przemianą manier a procesami społeczno-gospodarczymi jest zwyczaj wcześniejszego umawiania się na wizyty. Jak twierdzi M. Łozińska, w połowie XIX wieku znajdował on wielu zwolenników w zaborze pruskim, a zatem tam gdzie rozpowszechnione było wyobrażenie o pedanterii jako o ważnej cesze oraz gdzie rewolucja przemysłowa rozpoczęła się wcześniej. W Królestwie i na Kresach długo był natomiast nie do zaakceptowania. Jeszcze w dwudziestoleciu międzywojennym kresowa gościnność wzdragała się przed wymogiem listownego lub telefonicznego zapowiadania przyjazdu ${ }^{16}$.

Podobnie było w przypadku osób żyjących w gorszych warunkach na wsi. Do XIX wieku szczodre przyjmowanie gości, bez względu na stopień znajomości, było uważane za cechę dobrego gospodarza, niezależnie od jego statusu i kondycji finansowej.

Można zidentyfikować dwa prawdopodobnie najważniejsze czynniki ciągłości zwyczaju gościnności w środowisku chłopskim w Europie Środkowej. Pierwszym

\footnotetext{
${ }^{14}$ Ł. Gołębiowski, Domy i dwory..., s. 78-79.

${ }_{15}$ M. Łozińska, W ziemiańskim dworze. Codzienność, obyczaje, święta, zabawy, Warszawa 2010, s. $203-211$.

${ }^{16}$ Ibidem, s. 208-209.
} 
była moralność chrześcijańska i wpisane w nią miłosierdzie; z czasem niemal całkowicie straciły one bezpośrednie odniesienie do sfery sacrum. Na religijne podłoże gościnności chłopów wskazują przykłady wielu opowieści i legend zachodniosłowiańskich, które pozostawiły niezatarty ślad w bogatym materiale folklorystycznym. Pomimo różnic w szczegółach wspólnym mianownikiem licznych bajek i legend znanych na Słowacji i Morawach (częściowo odnoszących się do Wołochów, którzy wyemigrowali na Morawy w XIV-XVI wieku) ${ }^{17}$ jest fabuła opowiadająca o nagrodzie ofiarowanej przez „dawcę” najbiedniejszemu „bohaterowi” bajki za jego niezwykłą szczodrość i wielkoduszność okazane podczas przyjęcia gości ${ }^{18}$. Najsłynniejszym polskim odpowiednikiem takiej legendy jest o wiele późniejsza opowieść o Warsie i Sawie oraz ich dobroczyńcy Kazimierzu Odnowicielu ${ }^{19}$.

Inny czynnik gościnności w polskiej kulturze ludowej łączy się z instytucją rodziny i ze związanym z tym sposobem postrzegania przestrzeni domu. Tożsamość chłopska przednowoczesna była uzależniona od stosunków pokrewieństwa, hierarchii społecznej i przynależności terytorialnej. Jak zauważył Adam Pisarek w książce na temat polskiej gościnności:

kształt ludowych praktyk przyjmowania gości i systemu aksjonormatywnego z nimi związanego był po części wypadkową uzależnień sąsiedzkich, rodzinnych oraz tych, które łączyły wieś z dworem. Wraz z innymi formami opieki, hojności, pomocy wzajemnej i wymiany pozapieniężnej (często były one od owych form nieodróżnialne), praktyki te tworzyły i utrwalały dotychczasową strukturę społeczną, potwierdzały centralne dla danej kultury wartości oraz współkształtowały oparty na nich model współżycia i budowania (oraz wyobrażania sobie) więzi ${ }^{20}$.

Jeśli chodzi o dawne wzory przestrzenno-symboliczne, to etnolodzy wskazują na piec i stół - dwa centralne artefakty odgrywające niezwykłą rolę w zrozumieniu idei gościnności i tworzące podstawową dychotomię w chacie chłopskiej ${ }^{21}$. Ciekawe, że pomimo różnych źródeł etnicznych (słowiańskie i ugrofińskie) pochodzenia narodów Europy Środkowej kultura domowa przyjmowania gości, zwyczaje i normy zachowania w tym wzgędzie niewiele się różnią. Na przykład w tradycyjnej kulturze Węgrów również od gościa wymaga się dużego taktu. Ponieważ wcho-

${ }_{17}$ Zob. K. Ėrben, B. Nemcova, Â. Neruda, Bol'šoe sobranie predanij, skazok i mifov zapadnyh slavân, Moskva 2018.

${ }^{18}$ Nazwy aktorów bajek podane są za pracą Morfologia bajki magicznej radzieckiego folklorysty Władimira Proppa. Zob. V.Â. Propp, Morfologiâ volšebnoj skazki, Moskva 2001.

${ }_{19}$ To prawda, że opozycja wobec figury gościa Boga (dobroczyńcy), przybierająca w starożytnych podaniach formę gościa demona (złoczyńcy), bardzo długo pozostawała żywa w kulturze ludowej.

${ }^{20}$ A. Pisarek, Gościnność polska. O kulturowych konkretyzacjach idei, Katowice 2016, s. 62.

${ }^{21}$ Ibidem, s. 77. 
dzi on w przestrzeń prywatną rodziny i otrzymuje od niej kredyt zaufania, w żadnym wypadku nie powinien go nadużywać. $Z$ tego powodu prawa i obowiązki nie tylko gospodarza, lecz także gościa, były ściśle regulowane przez niepisane normy etyczne ${ }^{22}$.

Po zniesieniu poddaństwa i uzyskaniu przez chłopów prawa do własności rodzina przeszła proces indywidualizacji, który był związany $\mathrm{z}$ „usamodzielnieniem się rodziny chłopskiej jako jednostki gospodarczej”23. Na pierwszym miejscu pojawiła się rodzina nuklearna, co wraz z późniejszym rozwarstwieniem materialnym chłopstwa wpłynęło nie tylko na rozwój jego tradycji genealogicznej, lecz także na kulturę przyjmowania gości. Cytowany już A. Pisarek dość rozlegle wyjaśnia to w następujących słowach:

w sytuacji, gdy na wsi nie istniały złożone związki krewniacze, a gospodarka nie uległa jeszcze utowarowieniu i opierała się przede wszystkim na zasadzie samożywienia, rodzina tworząca domową grupę rezydencjalną była tą instytucją, która skoncentrowała większość istotnych funkcji, m.in. prokreacyjną, gospodarczą i socjalizacyjną. Stanowiła także podstawową jednostkę społeczno-przestrzenną kontrolującą krótko- i długotrwałe alianse jej członków. Wokół niej konstytuowały się także zrytualizowane formy przyjmowania różnorakich gości, choć zdarzało się, że pewne rozwiązania były wypracowywane również na poziomie ciał kolektywnych reprezentujących całą społeczność. Dalsze historyczne przekształcenia, związane z industrializacją i wyłanianiem się warstwy chłopo-robotniczej, skutkowały powstaniem warunków umożliwiających wykształcenie się nowych typów więzi (np. w ramach instytucji zakładu pracy). Opierały się one często na kategorii świadomego, indywidualnego i celowego wyboru. Zmniejszając siłę uwarunkowań terytorialnych, wpłynęły przy tym na zmianę charakteru dotychczasowych form przyjmowania gości. Mimo tego nie naruszyły wykształconej w opisanym tu modelu zasady organizującej większość wiejskich zwyczajów recepcyjnych wokół rodziny i jej domeny terytorialnej ${ }^{24}$.

Wynika z tego, że tradycja gościnności, która jest mocno zakorzeniona w mentalnym wizerunku mieszkańca Europy Środkowej, kształtowała się pod wpływem różnych ekonomicznych, kulturowych i społecznych czynników. Ważnymi zmien-

${ }^{22}$ A vendéglátás etikettje, w: Magyar néprajz, VIII Kötet. Társadalom, red. A. Paládi-Kovács, https://mek.oszk.hu/02100/02152/html/08/319.html (dostęp: 18.05.2020).

23 S. Szynkiewicz, Rodzina. Elementy systemu pokrewieństwa, w: Etnografia Polski. Przemiany kultury ludowej, red. M. Biernacka, Wrocław 1976, s. 481.

24 A. Pisarek, Gościnność polska..., s. 59-60. 
nymi w tym procesie były: status, formy dominacji, stopień pokrewieństwa i kapitał ekonomiczny.

W czasach średniowiecza dla różnych grup społecznych regionu Europy Środkowej istniało kilka systemów wzorców gościnności. Najpopularniejszymi z nich były: gościnność „przyjacielska”; płatna i bezosobowa gościnność zajazdów; gościnność właściwa instytucjom kościelnym, wzmacniana normami moralno-religijnymi; królewski lub seniorialny pobyt (servitium regis). Ten ostatni typ w Europie Środkowej utrzymał się przez dość długi czas w porównaniu z Europą Zachodnią.

Dodatkowym elementem przyczyniającym się do zachowania tradycji gościnności była struktura konsumpcji wyższych klas społecznych, przede wszystkim szlachty, która zajmowała korzystną pozycję w światowym podziale pracy. Nieco inaczej sytuacja w omawianym regionie zaczęła wyglądać od czasów industrializacji i związanej z nią gwałtownej urbanizacji, która finalnie doprowadziła do zmiany tradycji i norm behawioralnych.

W związku z tym można zgodzić się z opinią węgierskich naukowców, redaktorów zbioru artykułów etnograficznych Magyar néprajz. Ich zdaniem współcześnie instytucja gościnności przesuwa się w kierunku raczej reprezentowania statusu, często przekształcając poprzednie wartości gościn. Teraz są to albo coraz droższe zwyczaje świąteczne, albo spontaniczne, nie tak ściśle regulowane przyjmowanie gości, które zresztą zmienia się również z powodu rozwoju branży hotelarsko-restauracyjnej. Taka zmiana codziennych praktyk pokazuje przeobrażenia, jakim uległy funkcje samych gościn. Według autorów nabywają one cech samoreprezentacji rodziny, stają się częścią prestiżowej konkurencji, narzędziem do budowania relacji z innymi ludźmi i zarządzania nimi, zamiast podtrzymywać spójność społeczną lub być sposobem akumulacji kapitału symbolicznego ${ }^{25}$.

\section{Bibliografia}

A vendéglátás etikettje, w: Magyar néprajz, VIII Kötet. Társadalom, red. A. Paládi-Kovács, https://mek. oszk.hu/02100/02152/html/08/319.html (dostęp: 18.05.2020).

Brühl C., Fodrum, Gistum, Servitium Regis. Studien zu den wirtschaftlichen Grundlagen des Königtums im Frankenreich und in den fränkischen Nachfolgestaaten Deutschland, Frankreich und Italien, Köln 1968.

Bystroń J.S., Dzieje obyczajów w dawnej Polsce, t. 2: Wiek XVI-XVIII, Warszawa 1976.

Chodźko I., Obrazy litewskie, Kraków 2010.

Dubrovskij I.V., Gostepriimstvo, w: Slovar' srednevekovoj kul'tury, red. A.Â. Gurevič, Moskva 2003.

${ }^{25}$ A vendéglátás etikettje, w: Magyar néprajz, VIII Kötet. Társadalom, red. A. Paládi-Kovács, https://mek.oszk.hu/02100/02152/html/08/319.html (dostęp: 18.05.2020). 
Elìas N., Proces civilizaciï. Sociogenetični i psihogenetični doslidžennâ, perekl. O. Logvinenko, Kï̈v 2003.

Èrben K., Nemcova B., Neruda Â., Bolšsoe sobranie predanij, skazok i mifov zapadnyh slavân, Moskva 2018.

Frazer J.G., Złota gałąz. Studia z magii i religii, Warszawa 2017.

Gołębiowski Ł., Domy i dwory. Przy tem opisanie apteczki, kuchni, stołów, uczt, biesiad, trunków i pijatyki; łaźni i kąpieli; łóżek, pościeli, ogrodów, powozów i koni; błaznów, karłów, wszelkich zwyczajów dworskich i różnych obyczajowych szczegótów, Warszawa 1830.

Łozińska M., W ziemiańskim dworze. Codzienność, obyczaje, święta, zabawy, Warszawa 2010.

Mal'dzìs A., Belarus' u lûstèrku memuarnaj Litaratury xviii stagoddzâ: narysy bytu i zvičaâ, Mìnsk 1982.

Modzelewski K., Organizacja gospodarcza państwa piastowskiego X-XIII wiek, Poznań 2000.

Orman E., Krytyka sarmackiego ucztowania oparta na fragmentach tekstów literackich i piśmienniczych dawnych, „Ogrody Nauk i Sztuk” 2011, nr 1, s. 311-320.

Pisarek A., Gościnność polska. O kulturowych konkretyzacjach idei, Katowice 2016.

Propp V.Â., Morfologiâ volšebnoj skazki, Moskva 2001.

Szynkiewicz S., Rodzina. Elementy systemu pokrewieństwa, w: Etnografia Polski. Przemiany kultury ludowej, red. M. Biernacka,Wrocław 1976.

Topolski J., Historia Polski, Poznań 2015.

Veber M., Protestantskaâ ètika i duh kapitalizma, Moskva 1990.

Ihor Usatenko

The Phenomenon of Central European Hospitality in Historical Terms

Summary

This article examines the phenomenon of hospitality from a historical perspective. The author's aim is to show that the tradition of hospitality in the Central European region has deep historical roots, and that it is also strongly linked to various socio-political and economic processes that took place in different historical epochs.

Key words: hospitality, Old-Polish hospitality, Central Europe 